Advanced Computing: An International Journal ( ACIJ ), Vol.4, No.1, January 2013

\title{
VERITAS MOUSEION 3D - TECHNOLOGY AND MUSEUM INFORMATION
}

\author{
Janaina Mello ${ }^{1}$ and Irla Rocha ${ }^{2}$ \\ ${ }^{1}$ Department of Museology, Federal University of Sergipe, Laranjeiras, Brazil \\ Janainamello.ufs@gmail.com \\ ${ }^{2}$ Department of Literature, Federal University of Sergipe, São Cristóvão, Brazil \\ irlasuellen@gmail.com
}

\begin{abstract}
The Veritas Mouseion is an Electronic Dictionary of terms museum organized from interviews with professional museological institutions for the definition, etymology and homogenization of the entries in a cloud computing environment, audiovisual, 3D, organizing the information and data available to the user via PCs, tablets, smartphones and ebooks.
\end{abstract}

\section{KEYWORDS}

Electronic dictionary, museum, dimensional collections, computing, information

\section{INTRODUCTION}

The Veritas Mouseion is an original product of a technological innovation that captures research and development of computational tools for access and interactivity in the field of Museology and other humanities and social sciences related to work on museological institutions.

Assuming that a museum is the embodiment of the collective memory, configured as an issue of discourse, electronic dictionary entries Veritas Mouseion presents audiovisual communication technology expands the cloud with users through 3D interactivity.

The structural organization of the dictionary follows the methodology of implementation of thesaurus, based on the hierarchy of subjects in an associative relationship and not simply isolated words conceptualized in alphabetical order [1].

As objective we seek to scanning and 3D modeling of collections exhibition of Sergipe at three institutions picking up the dictionary entries electronic interactive touch screen application for accessibility playful and innovative with the display of objects converted to photographic image with 360 degree rotation and 3D conceptual modeling. Section 2 At the Museu do Homem Sergipano (MUHSE) is the proposed the preparation of digital entries. Section 3 At the Museu Galdino Bicho at Instituto Histórico e Geográfico Sergipano (IHGSE) introduces the underpinning principles for building digital collections. Section 4 At the Museu de Arqueologia de Xingó (MAX) provides a case study of 3D using free softwares.

\section{MuSEU do HoMem SERGIPANO AND DigITAL ENTRIES}

The Museu do Homem Sergipano (MUHSE) was created to manage the Rector Professor Joseph Aloisio Field by group of professors in the Department of Psychological Sciences, Sociological and Anthropological (DCPSA), Federal University of Sergipe (UFS) in 1976[2]. 
The goal of the museum and its creation, from the collections, was to keep the memory of their ancestors through objects and documentation in support of processed information. Thus the Museu do Homem Sergipano has a rich collection of ceramics, photographs, paintings, books, among other objects.

\subsection{Museology, terminology and digital entry}

A search of the prior National Institute of Industrial Property (INPI) - responsible for registering trademarks and patents - not detected the existence of a computerized dictionary containing terms related to Museology in Portuguese. To build the corpus terminology was held a screening of terms by selecting/extracting a vocabulary museum.

The construction of the entries is accomplished through multi-institutional collaborations and interdisciplinary based on Pedagogical Project Graduation in Museology at the Federal University of Sergipe (eg. Figure 1), structured as follows:
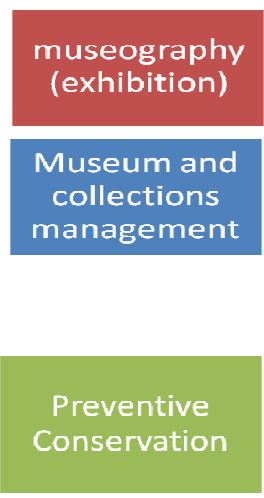

Museological

Information and Documentation
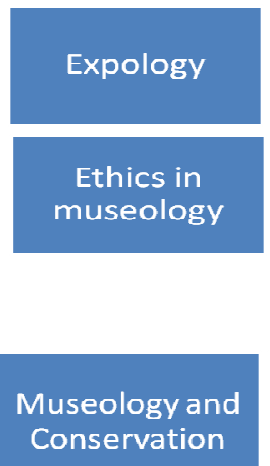

Ethics in museology

Museology,

Heritage and Memory

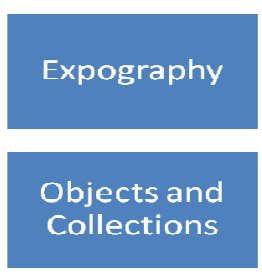

Museology and Preventive Conservation

Museology and Social

Development
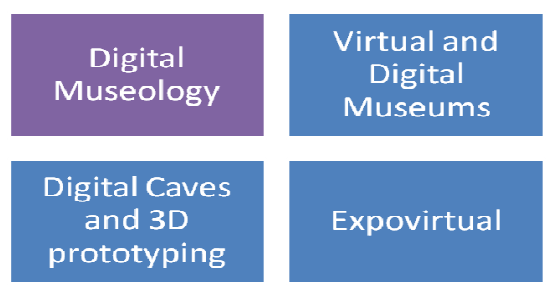

Architecture
Museum

Museology and

Information

Systems 


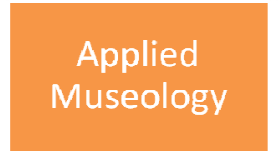

Educational

Activities in

Museums
Heritage

Education

Evaluating

Public
Natural

Heritage

Special

Education in

Museums

Figure 1. Diagram of Pedagogic Project of undergraduate Museology (UFS)

The methodology for developing the electronic dictionary includes interviews with professionals from various museums; application of thesaurus and rotational and 3D modelling of collections.

\subsection{Museums, interviews and digital entries}

In Brazil, the first degree in Museology was founded in 1979 at the Federal University of the State of Rio de Janeiro (UNIRIO) [3] and in 2007 the Federal University of Sergipe deployed in the city of Laranjeiras (SE), the undergraduate course in Museology. In 2009 we have the creation of the body that is responsible for the National Museum and the improvement of the services sector, the Brazilian Institute of Museums (IBRAM), a federal agency under the Ministry of Culture (MINC).

According to Cury [4], the public museum has increased their awareness of their rights subject to the process of cultural interpretation of cultural heritage musealized. This coincides with the care of linguistic studies during the construction of the meaning of vocabulary specific terminology, and the goal of this research project in terms of ease of understanding between students and museum professionals and without knowledge or academic training in Museology.

From the perspective of Cury, Museology Digital space is the branch of science museum that allows greater interaction with the museum's new user: what comments and shares his impressions on major network (internet). From the interviews collected can configure a model terminological (eg. Table 1):

Table 1. Interviews and Digital Entries by Joelma Matias (2012).

\begin{tabular}{|l|l|l|}
\hline Interviewee & Job & Digital entries \\
\hline $\begin{array}{l}\text { Nunes, Verônica } \\
\text { Maria M. }\end{array}$ & $\begin{array}{l}\text { Director of the Museu } \\
\text { do Homem Sergipano } \\
\text { (MUHSE) in Aracaju - } \\
\text { SE }\end{array}$ & $\begin{array}{l}\text { Museum Object "is an artifact of society, } \\
\text { man's own product, and what was done to meet } \\
\text { the needs of the present." } \\
\text { Technical Reserves "are spaces guard of all } \\
\text { museum objects that are not on display [...]." } \\
\text { Collection "is the ordering of a group of } \\
\text { objects from the origin [...]." }\end{array}$ \\
\hline $\begin{array}{l}\text { Oliveira, } \\
\text { Ludmilla Silva }\end{array}$ & $\begin{array}{l}\text { Museologist at } \\
\text { Museum Antonio }\end{array}$ & $\begin{array}{l}\text { to give an air of realism to a particular context } \\
\text { can be a landscape or a historical moment }\end{array}$ \\
\hline
\end{tabular}




\begin{tabular}{|l|l|l|}
\hline de & $\begin{array}{l}\text { Nogueira in Itabaiana / } \\
\text { SE }\end{array}$ & $\begin{array}{l}{[\ldots . . . "} \\
\text { Sketch: [...] is a sketch, a doodle, a sketch [...] } \\
\text { idea of an instant, lest they lose the idea. " } \\
\text { Curator: "is the professional responsible for } \\
\text { the design, assembly and exhibition of certain } \\
\text { works [...]." }\end{array}$ \\
\hline $\begin{array}{l}\text { Lerqueira, Vera } \\
\text { Lúcia Cardin de }\end{array}$ & $\begin{array}{l}\text { Sociologist at Culture } \\
\text { Secretariat (SECULT / } \\
\text { SP) and employee of } \\
\text { Cultures Brazilian } \\
\text { Pavilion in São Paulo. } \\
\text { made from some records or objects." } \\
\text { Collection "is a collection of records, objects } \\
\text { that are part of the same issue or have any } \\
\text { significant axis [...]." } \\
\text { Collection: "may be a set of objects or records } \\
\text { that may hold different collections, ie, different } \\
\text { sets itself [...]." }\end{array}$ \\
\hline
\end{tabular}

Machado [5] reveals that a search model should meet the needs of a society in constant transformation process, which has the scientific knowledge as a structural component, striving for the creation of a complex innovation, and serving as a laboratory for the generation of technology.

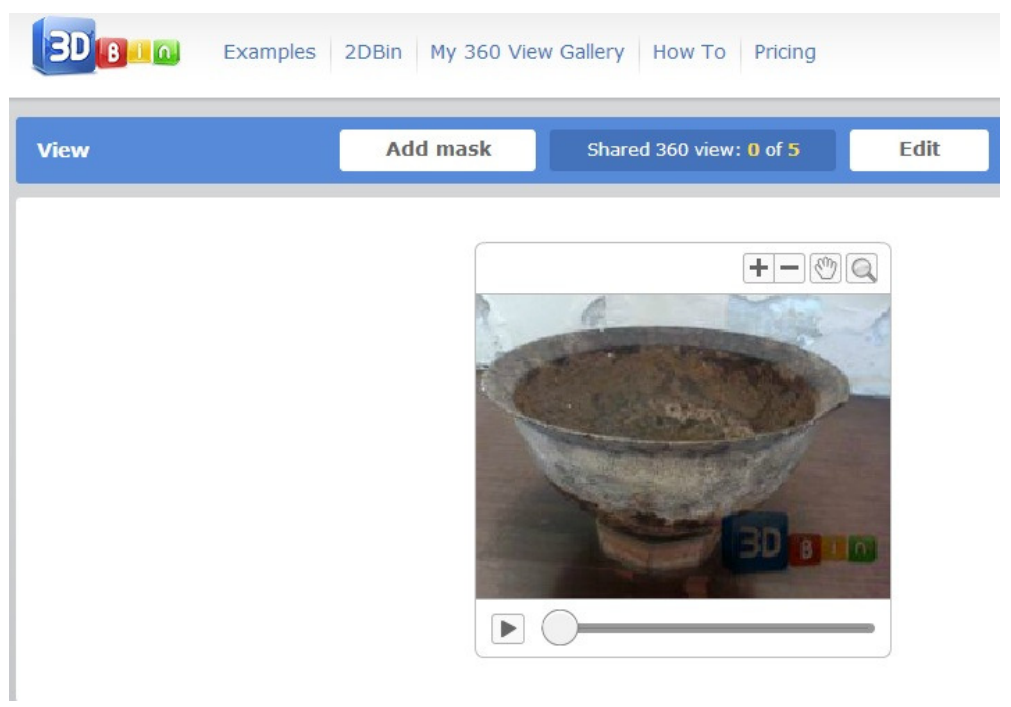

Figure 2. Iron Vase Museu do Homem Sergipano, 2012, by Janaina Mello

We decided to use the program online 3D Bin a software with a user friendly interface, low cost and high quality resolution for $360^{\circ}$ photography of objects. After uploading the images into a rotational sequence is the automatic processing of the object, creating a flash video file that allows visitors to learn the details of moving and using a magnifying glass approach the piece.

\section{Museu Galdino Bicho at Instituto Histórico e Geográfico SERGIPANO (IHGSE)}

The Instituto Histórico e Geográfico Sergipano (IHGSE) houses a small amount of diverse objects in a single room museum named Galdino Bicho [6]. There is this space a rich historical, 
ethnographic, archaeological, imagery, military, among other classifications, with a collection of various types and origins [7].

Considered one of the first museums of Sergipe, created in 1912, the institution has a funerary urn up military outfits, thus building an environment that gathers facts that underscore the memory of Sergipe.

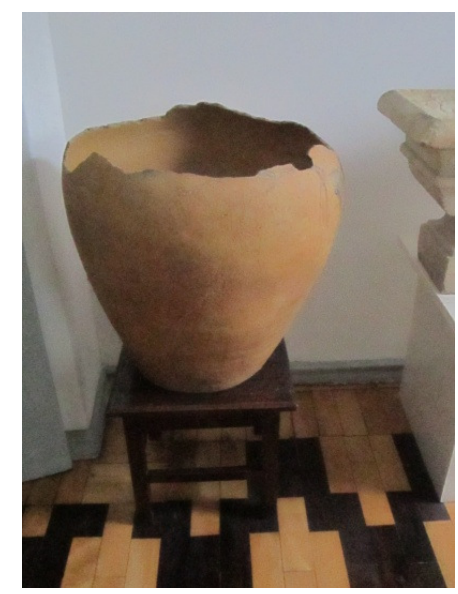

Figure 3. Ceramic urn, Museum Gladino Bicho - SE, by Estefanni Patricia Santos (2012)

Veritas Mouseion 3D design seeks to give the expansion of the visits to the Museum Galdino Bicho, academic research and the use of integrated technological experimentation for continuous updating of officials of the cultural institutions. The collaborative nature of the dictionary allows through the terms museum built by professionals of different levels of training and greater geographic origins of communicative interaction museum.

\section{Museu de ArQueologia do Xingó (MAX)}

The Museum of Archaeology Xingó (MAX) Canindé in San Francisco, a city 203 km away from Sergipe in Aracaju, is maintained by the Federal University of Sergipe (UFS), in partnership with the Hydroelectric Company of San Francisco (CHESF). Founded in 2000, appeared to allow the research and preservation of the archaeological heritage of the Lower San Francisco resulting from archaeological rescue performed by the UFS from 1988 to 1997.

The archaeological collection brings together approximately 55 thousand pieces: human skeletons, utensils and graphic records that demonstrate aspects of the culture of the man who was already in the region for at least 9000 years.

The collection of ceramic MAX corresponding to a total of 43 canisters of Sites Justin and St. Joseph 1 and 2 [8]. Thus the 3D treatment to the collection of archaeological ceramic MAX allows the inclusion of new technological tools for information and communication.

Apply techniques of 3D scanning in the 43 ceramic artifacts part of the Museum of Archaeology Xingó contributes to a Public Archaeology [9] effective and efficient, able to save, preserve and promote this cultural heritage.

After reading about scanning, picture rotating $360^{\circ}$ and $3 \mathrm{D}$ conceptual modeling of museum collections, began to step photographs and digitization of collections. The third step comprises the application software as Blender and / or illusion of Art; 3Dbin and / or Object2VR 360 in modeling and 3D parts photographed and / or scanned. The use of the software in generating 
technological product in the area of heritage involves: analysis, design, implementation, testing and validation. Following the acquisition of images or videos it produces a $3 \mathrm{D}$ model at $360^{\circ}$ in Flash, HTML gift or published in a database on the Internet. In another step inserts the material rotating $360^{\circ}$ and $3 \mathrm{D}$ environment in the electronic dictionary, linking image / entry and introduction of software as the Dos-vox [10] to promote accessibility for blind people.
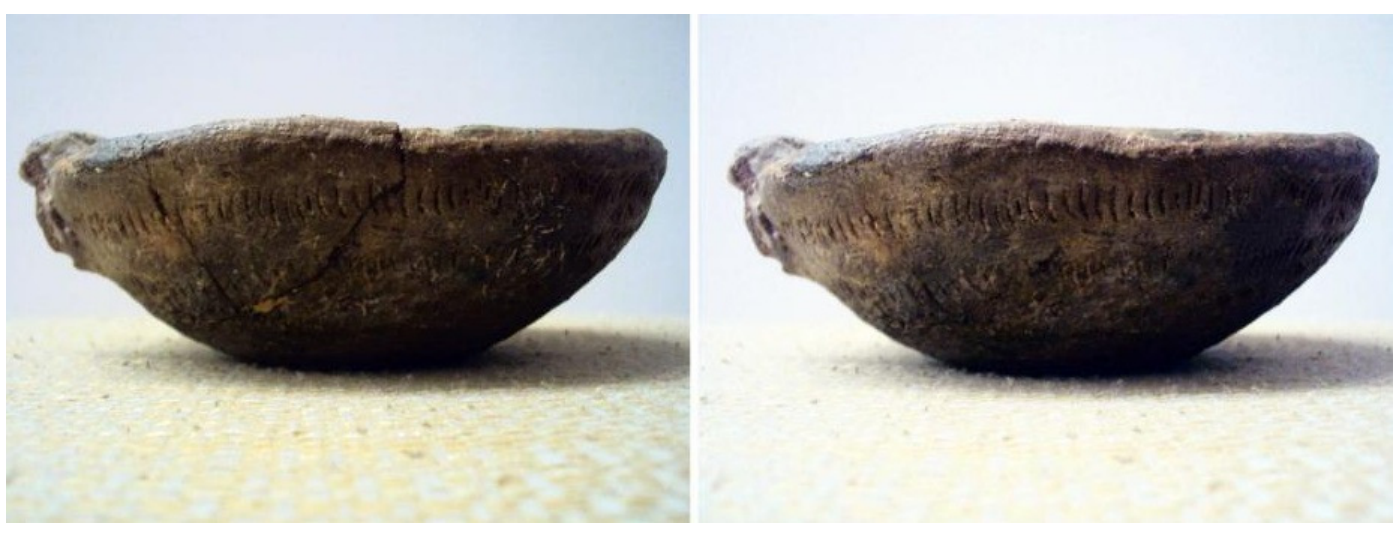

Figure 4. Ceramics MAX, original and restored, by Raquel Figueirôa (2012)

\section{Conclusions}

In the active process of language development, in our case for the development of the concepts of the terms in a digital environment, memory works as the site on which registered the concepts, worldviews, values, identities and ideologies of society through professional museum. The conceptualization of words results from dynamic experiments in which the human being passes throughout his life. "Words label cognitive processes by which man interacts with his environment cognitively"[11]. The relationship between memory and culture is characterized by social function that they provide through the communicative character that exists between them and that for purposes of research carried out by means of language.

The development of an electronic product in partnership with the Centre for Innovation and Technology Transfer (CINTEC-UFS) promotes interdisciplinary research for technological application in Museology. Thus, the electronic dictionary of terms museum is configured as an instrument of digital information, software designed as a cloud, storing information arranged through audiovisual resources, using videos, sound files, photographs and 3D images, which facilitate the understanding of fixing terms and their meaning, providing greater ease of sense employed by the dictionary in everyday professional and scientific museum.

\section{ACKNOWLEDGEMENTS}

To Centre for Innovation and Technology Transfer (CINTEC-UFS), FAPITEC-SE and CNPq.

\section{REFERENCES}

[1] Dias, C.A., (2000). "Terminologia: conceitos e aplicações" [Terminology: concepts and applications], Ci. Inf., Brasília, Vol. 29, No. 1, pp. 90-92.

[2] Silva, V.M., (2012). Coleção Carrapicho: a trajetória das cerâmicas expostas no Museu do Homem Sergipano (1983-2012) [Carrapicho Collection: the trajectory of ceramics exhibited in the Museum of Man Sergipano (1983-2012)]. Laranjeiras-SE, UFS. p.37. 
[3] The idea of a Course Museum dates back to the creation of the National Historical Museum MHN, in Rio de Janeiro in 1922, designed by Gustavo Dodt Barroso, politician and writer, member of the Brazilian Academy of Letters and one of the most active intellectual from regionalism and nationalism at the first decades of the twentieth century. But it was only in the management of the historian Rodolfo Garcia as Director of MHN which was effectively created a Course of Technical Museums (Decree that created it, No. 21129, March 7, 1932).

[4] Cury, M. X. (2007) Comunicação museológica em museu universitário: pesquisa e aplicação no Museu de Arqueologia e Etnologia-USP. [Museum Communication in university museum: research and application in the Museum of Archaeology and Ethnology-USP]. Disponible: http://www.revistasusp.sibi.usp.br/pdf/cpc/n3/a05n3.pdf. (Acess: 20/09/2012).

[5] Machado, E. 2003. O ciberespaço como fonte para jornalistas [Cyberspace as a source for journalists]. Salvador, Calandra, p.44.

[6] Artist born in Rio de Janeiro who portrayed the state of Sergipe in his paintings. After his death a valuable iconographic collection was donated to IHGSE.

[7] FREITAS, Itamar. 2002. A escrita da história na "Casa de Sergipe" (1913- 1999) [The writing of history in "Casa de Sergipe" (1913 - 1999)]. São Cristóvão: Ed. UFS; Aracaju: Fundação Oviêdo Teixeira.

[8] The St. Joseph sites I and II are located at Fazenda São José, in the municipality of Delmiro Gouveia (AL), on a high terrace by the river São Francisco.

[9] Pedro Paulo A. Funari. (Org.). 2010. Public Archaeology. 1 ed. Oxford: Archaeopress, v. 1, p. 914

[10] The DOSVOX operating system, created by the Federal University of Rio de Janeiro (UFRJ), enables blind people to use a common microcomputer (PC) to perform a series of tasks, thus gaining a high level of independence in study and work.

[11] Biderman, M. T. C. (1998) "Dimensões da palavra" ["Dimensions of the word"], Filologia $e$ Lingüística Portuguesa, n. 2, p. 81-118, 1998. Lenneberg, E. H.; Lenneberg, E. (Eds.), (1975) Foundations of language Development: A Multidisciplinary Approach. New York and Paris: Academic Press and Unesco Press, p.374.

\section{Authors}

Janaina Mello is a $\mathrm{PhD}$ at History and Professor at Museology Department Federal University of Sergipe. Her current research interests are computing and technology applied to the humanities and social sciences.

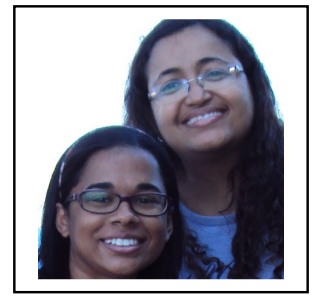

Irla Rocha is student Literature Department at Federal University of Sergipe. Her current research interests are computing and technology applied to linguistics. Fellow PIBITI/ CNPQ. 